\title{
EVALUATION OF STRUCTURAL ELEMENTS AND MODELING OF ÇARDAK KHAN ${ }^{*}$
}

\author{
Esra ŞAHİN ${ }^{1}$
}

${ }^{1}$ Ögr. Gör., Department of Construction Technology, Istanbul Aydin University, Istanbul, Turkey, esrasahin3@aydin.edu.tr, ORCID: 0000-0001-5842-9115

\begin{abstract}
Historical masonry structures are of great importance in terms of transmitting our cultural heritage to future generations. In order to protect these masonry structures, it is necessary to evaluate the structural elements and model the building. In this study, it is aimed to model a historical building and present the structural elements depending on the current situation. The Çardak caravanserai in Denizli, which was built in the Seljuk Period, was chosen as a case study because it preserves its originality and integrity. In this context, the software used for modeling is SAP2000 v20.2 commercial finite element analysis and design software. For modeling, frame elements were used in columns, and shell elements were used in other structural elements. As a result, the structural elements were interpreted and the model was applied.
\end{abstract}

Keywords: Historical Structure, Caravanserai, Modeling, Structural Element

\section{INTRODUCTION}

Çardak caravanserai in Denizli, known as Han-abad, was built by Esedüddin Ayaz bin Abdullah Eş-Şihabi in 1230 during Alaeddin Keykubad period. The caravanserai is 55 $\mathrm{km}$ to the east of Denizli and $300 \mathrm{~m}$ to the north of Denizli-Afyon highway, connected to Çardak province. It continued to be used during the Beylik and Ottoman periods. Hanabad was used for cereal storage during World War 1 (1914-1918) and the Turkish War of Independence (1920-1922) [1]. Shortly after that, the local people used it as a sheepfold [2]. The 800-year-old monument has suffered many earthquakes and it has been subjected to excavations and restoration works throughout history. It was restored in the 1920s. Excavations were carried out at the caravanserai in 2006. The restoration works have continued, which started in 2017 [3,4].

Many artistic and architectural works have been done in Çardak caravanserai. The building elements and modeling of the historical building were made as a thesis study in 2019 and were edited as an article. In addition, the structural analyzes of the Çardak Khan were presented at ISPEC 9th International Science and Engineering Congress and published in the book.

\footnotetext{
${ }^{1 *}$ Received: 06.01.2021 - Accepted: 12.01.2021

DOI: 10.17932/EJEAS.2021.024/ejeas_v01i1002
} 


\section{STRUCTURAL SYSTEM}

The monument located in the east-west direction is formed a rectangular courtyard (32.27 $\mathrm{m}$ in length, $31.16 \mathrm{~m}$ in width) with building ruins and a prismatic shelter $(29.23 \mathrm{~m}$ in length, $26 \mathrm{~m}$ in height) entered from the courtyard as shown in figure 1 . The northern part of the courtyard is in ruins. These parts consist of various functions such as the bath, kitchen, storage, workshop, staff room and iwan. The shelter to the west of the courtyard is a vaulted building consisting of a single space. The length and weight of the shelter are $29.23 \mathrm{~m}$. and $26 \mathrm{~m}$., respectively. There are five barrel-vaulted galleries in the east-west direction. In addition, there are pierced walls separating the central walls. The height of the central gallery is $5.40 \mathrm{~m}$. The vaults, which are $4.60 \mathrm{~m}$ high, descend from the center to the sides. Remains of low walls made of non-bearing walls also belong to the original platforms to accommodate people and belongings. The small ventilation holes in the vaults allow light to enter the shelter. The only opening at ground level is the portal. There are circular buttresses on both sides of the portal. Other buttresses have triangular and polygonal shapes. These buttresses ensure that the caravanserai is equally supported from both sides. Also, the caravanserai has a terrace. There is a staircase made of cut stone on the southeast side that enables access to this terrace $[3,4]$.

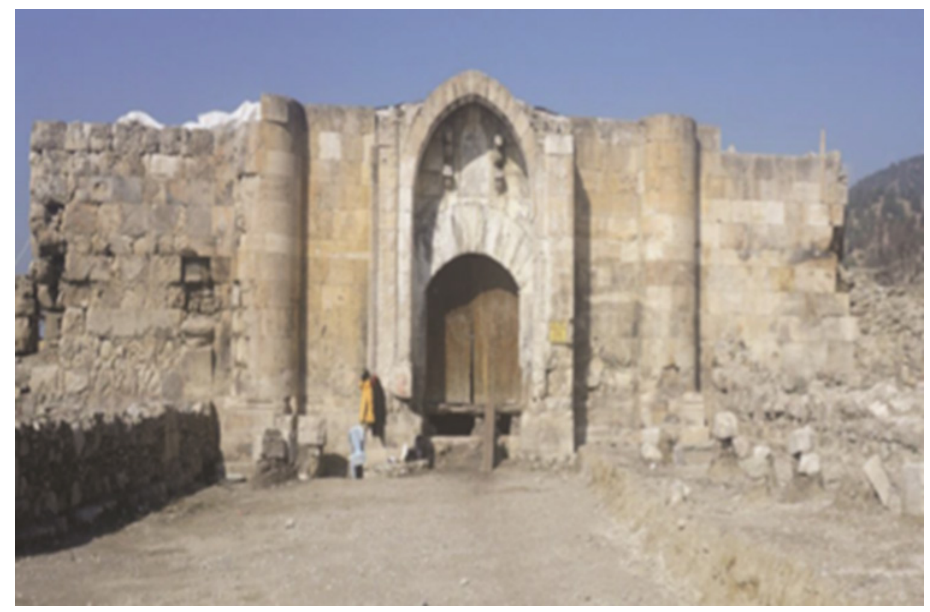

Figure 1: Çardak Khan

\section{STRUCTURAL ELEMENTS}

Structural elements occur the superstructural elements, walls and buttresses, floor and staircase, and foundations.

Superstructural elements consist of vaults, arches, the squinch remain and a concrete slab as shown in figure 2. The barrel vaults of the shelter are located in east-west direction as shown in figure 3. The spanning distance at the center is $4.50 \mathrm{~m}$, while it diminishes to $3.58 \mathrm{~m}$ and $1.97 \mathrm{~m}$ in the vaults at its north, and $3.06 \mathrm{~m}$ and $1.50 \mathrm{~m}$ in the vaults its south, respectively. Their heights are $3.10 \mathrm{~m}, 3.11 \mathrm{~m}, 3.37 \mathrm{~m}, 3.14 \mathrm{~m}$ and $2.98 \mathrm{~m}$ respectively from the north to the south. Their profiles are double centered and pointed as shown in figure 4 . They are out of rubble stone put together with lime mortar. At their exterior, earthen finishing is observed. There are ventilation holes along the keystones of the vaults. Just under the springing line of the vaults, the construction holes are still observable [3]. 


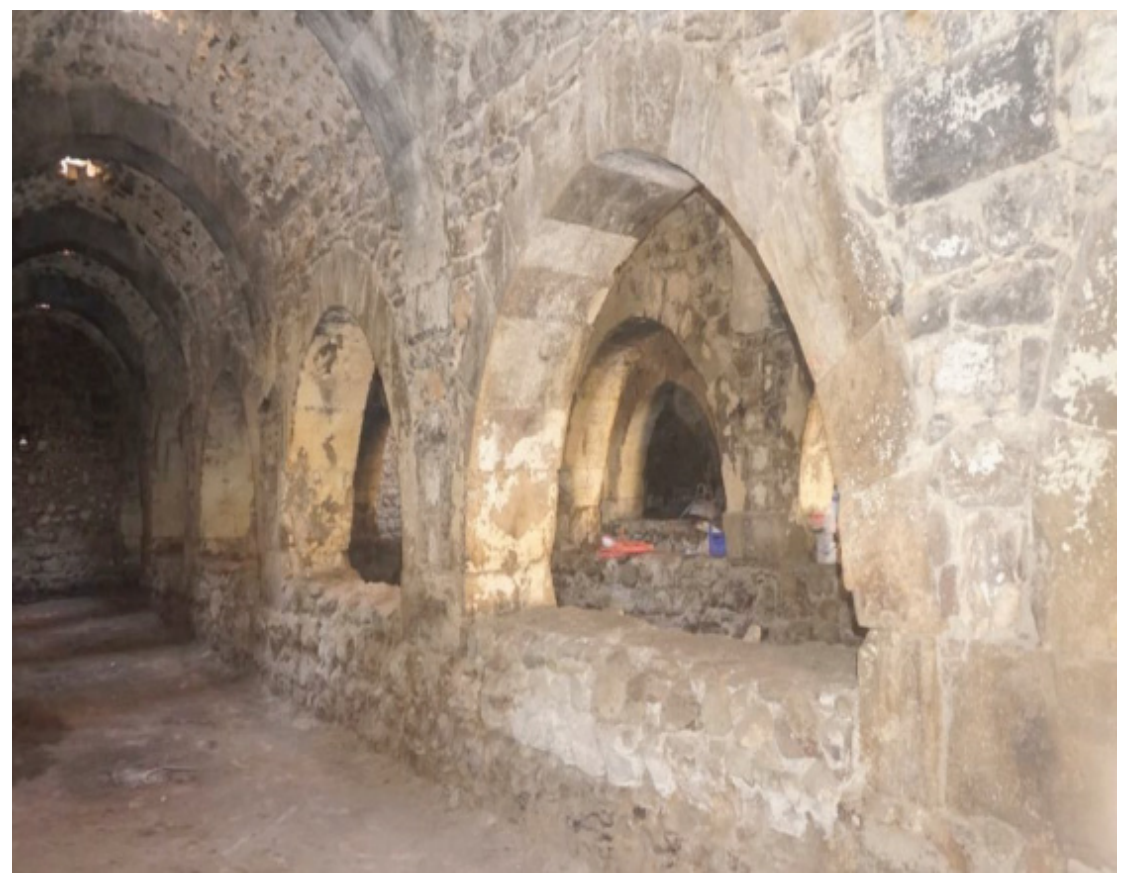

Figure 2: Superstructure Elements as Viewed from The West

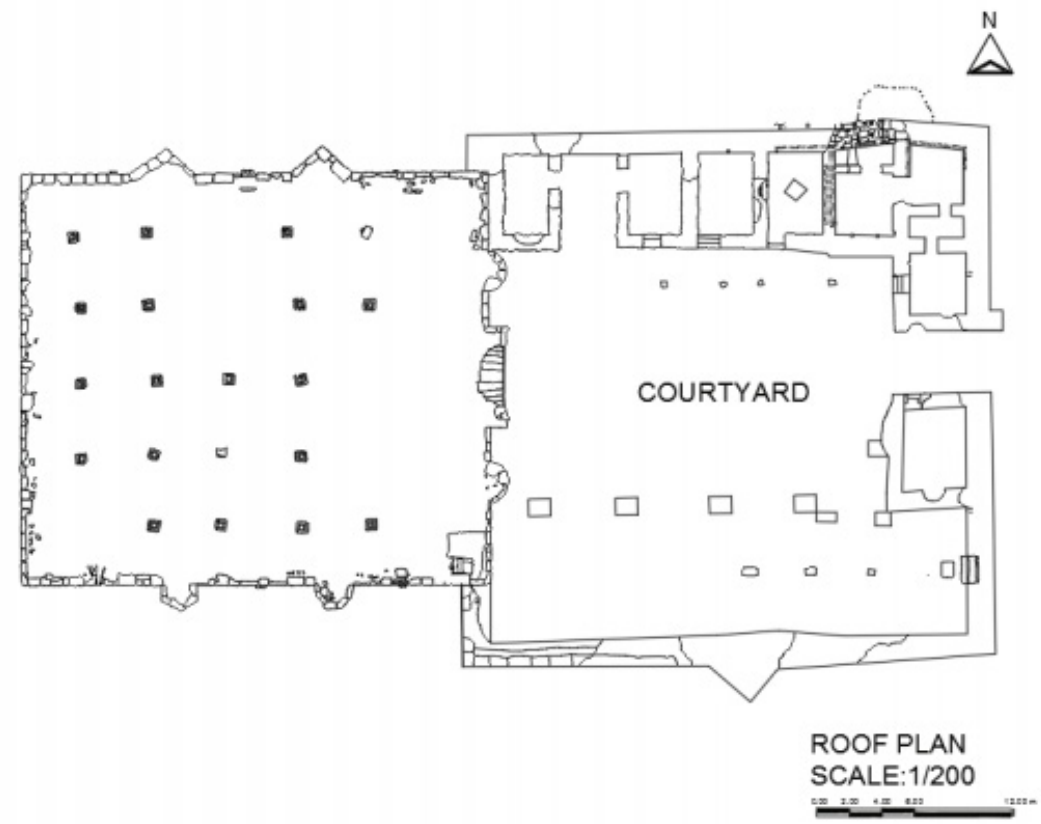

Figure 3: Roof Plan [5] 


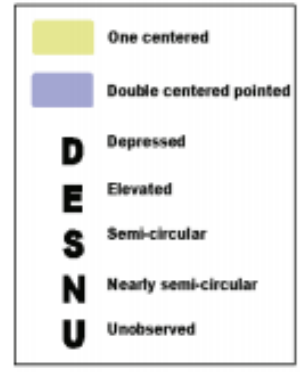

Figure 4: Vault and Arch [5]

The load-bearing exterior walls of the shelter are continuous walls. The eastern and southern ones that used to be observed from the old caravan route are out of well-cut stone at their outer surface, rough cut stone at inner surface and rubble stone and lime mortar in between as seen in figure 5. The western and northern walls that were designed as rear facades are out of relatively low-quality cut stone at their outer surfaces, rough cut stone at inner surface and rubble stone in between. The widths of northern and southern walls carrying the loads of the vaults are $1.80 \mathrm{~m}$ and $2.20 \mathrm{~m}$, respectively. The widths of 29 the western and eastern walls carrying their own loads are $1.40 \mathrm{~m}$ and $1.70 \mathrm{~m}$, respectively [3].

These walls are supported with buttresses from their exteriors, excluding the western one. There are two buttresses distributed evenly at each facade. Their forms are triangular (width: $375 \mathrm{~cm}$, projection: $24 \mathrm{~cm}$, height: $3.68 \mathrm{~m}$ ), circular (width: $193 \mathrm{~cm}$, projection: $110 \mathrm{~cm}$, height: $5.27 \mathrm{~m}$ ) and polygonal (width: $213 \mathrm{~cm}$, projection: $121 \mathrm{~cm}$, height: 4.80 m) starting from the north in clockwise order [3].

The interior load bearing wall of the shelter in figure 6, which are pierced with arches, are cut stone at their both surfaces. Their sections are unobserved. Their widths are 85 $\mathrm{cm}$ and $87.5 \mathrm{~cm}$ from the north to the south. The surfaces facing the central gallery are decorated with pilasters and animal figures. The non-load bearing walls at the interior belong to the original platforms for resting of people. At present, they define two $u$ forms at the second and fourth galleries from the north to the south. They are single layered and out of rubble stone and lime mortar. Their widths are the same as the related load bearing wall. As the construction joints reveal, the service spaces around the courtyard were constructed after the completion of the shelter walls. Nevertheless, their techniques are very similar. Thus, there is not a period difference. The load-bearing exterior walls of the 
service spaces around the courtyard are also continuous and three layered. The difference in the elaboration of front and rear facades 31 is visible here as well. They are well cut stone and relatively low-quality cut stone at the outer surfaces of the front and rear facades, respectively. The interior surfaces are rough cut stone and the cores are rubble stone and lime mortar. Only at the middle portion of the northern wall, which corresponds to the bath ruins, a different technique is observed: rough cut stone at both surfaces, and rubble stone and lime mortar in between. There is a triangular buttress (width: $229 \mathrm{~cm}$, projection: $30 \mathrm{~cm}$, height: $170 \mathrm{~cm}$ ) supporting the southern wall. The widths are 104 , 106,110 and $105 \mathrm{~cm}$, starting from the north in clockwise order. They are all partially collapsed and the maximum height observed is $1.85 \mathrm{~m}$ at the courtyard wall [3].

\section{Courtyard Walls}

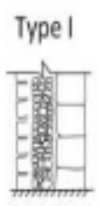

Section

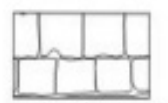

Front Elevation

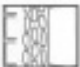

Top Elevation

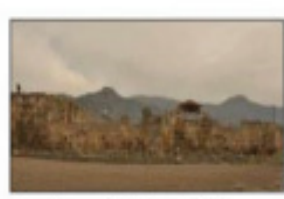

Southern Exterior Wall

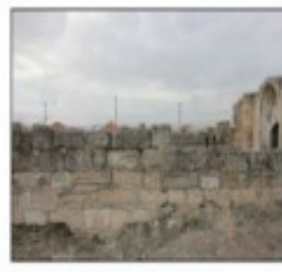

Northern Exterior Wall

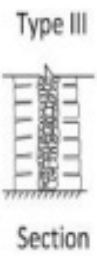

Type IV

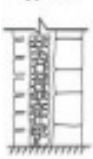

Section

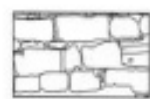

Front Elevation

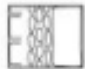

Top Elevation

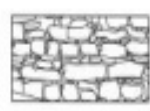

Front Elevation

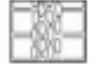

Top Elevation

Northem Exterior Wall, Bath Zone

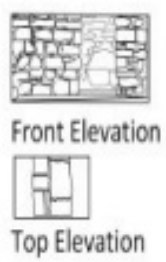

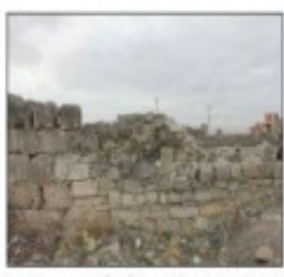

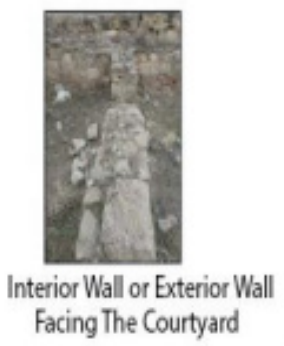

WALL DETAIL.

Figure 5: Wall Detail [5]

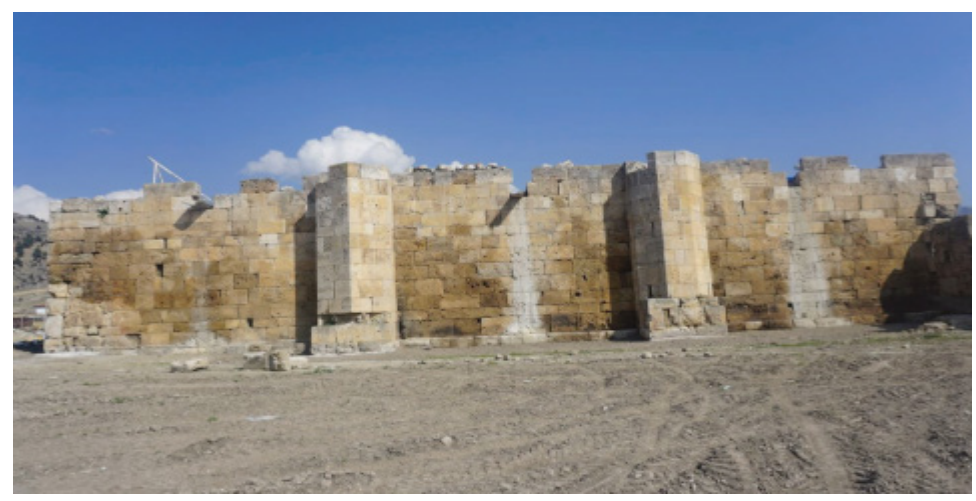

Figure 6: Interior Load Bearing Wall from Its Southeast 
The ground of the shelter is screed at present. As the sampling excavations reveal, original rubble stone and compacted earth are present underneath the intervention layer as seen in figure 7. The courtyard is covered with debris in general. The staircase in figure 7 at the southeast corner of the shelter links the interior to the terrace roof. It is L formed; the lower portion is parallel to the eastern wall (width $35 \mathrm{~cm}$, length $1.05 \mathrm{~m}$ ), the upper portion is parallel to the southern wall (width $32 \mathrm{~cm}$, length $1.25 \mathrm{~m}$ ). The stairs are out of cut stone block, each approximately $30 \mathrm{~cm}$ in height [3].

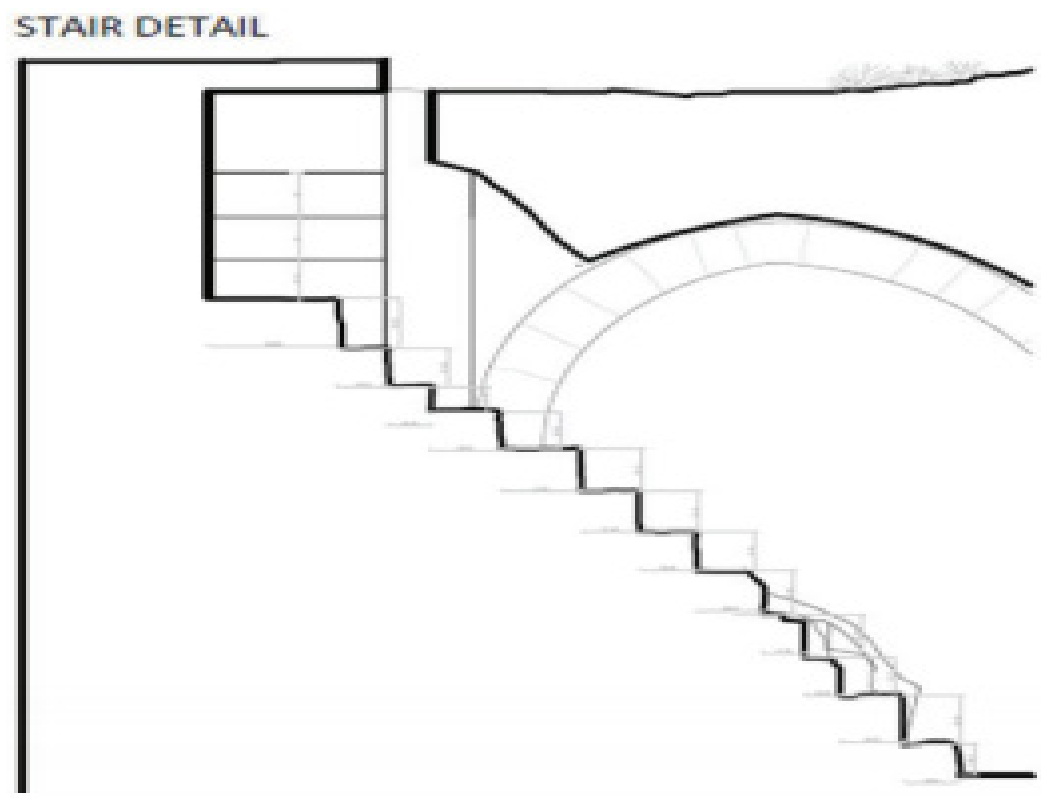

Figure 7: Stair Detail [5]

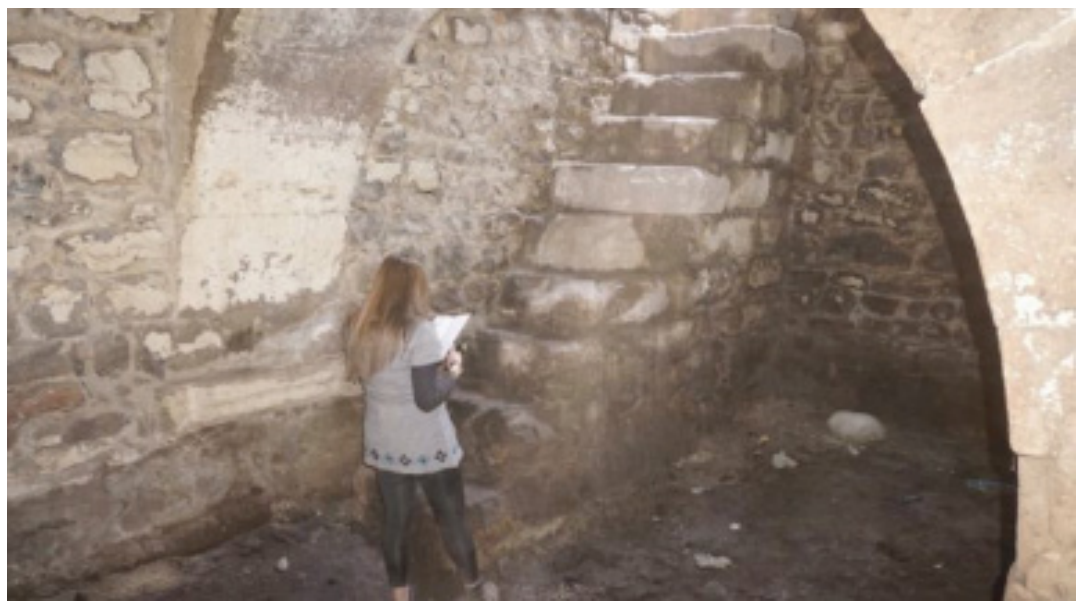

Figure 8: The Staircase 
As the sampling excavations reveal, the foundations continue underneath the interior walls (non-load bearing walls) of the shelter and the interior walls of the service spaces as shown in figure 8. They are out of rubble stone [3].

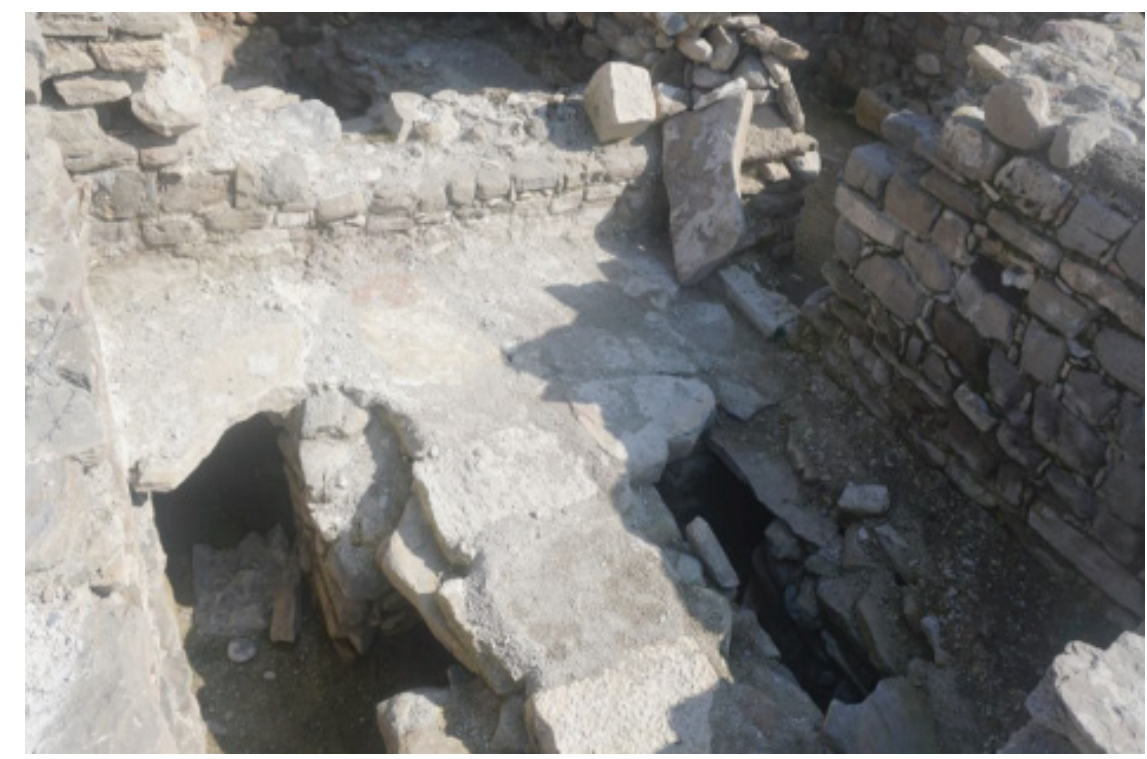

Figure 9: The Foundations at The North

\section{FINITE ELEMENT MODELING}

Due to the complexity of load-bearing systems such as domes, vaults, and arches in historical masonry structures and the materials of these structures, some difficulties arise in the generation of finite elements in these structures. In order to minimize these difficulties, some simplifications in the varying cross-sections of the load-bearing elements and some idealization in material and geometry require [6].

In recent years, with the development of computer technology, geometric and material idealization has emerged in the finite element modeling of masonry structures. In geometric idealization, structural elements such as dome, vault and arch consist of linear parts for modeling. In material idealization, all elements are accepted as linear elastic since the building elements consist of brick and mortar. Thus, all structural elements are homogenized to a single elastic material [7].

The architectural plans and sections of the caravanserai were drawn in AutoCAD format [5]. Three-dimensional model was developed according to this format and SAP2000 version 20.2 was used for modeling the masonry structure as seen in figure 9-13.

Frame and shell elements are used for the finite element model. While the frame element is suitable for the use of columns, shell elements are used in other elements such as dome, wall, vault, arch. The shell elements are divided into finite elements (mesh) to match boundary conditions. It was applied with the maximum unit side length of each partition 
of $30 \mathrm{~cm}$. The pin support is defined at the base of the three dimensional model. The mass source is specified as dead load [4].

According to the literature, the modeling techniques of masonry structures for finite elements consist of two parts, macro and micro modeling [8]. The modeling technique used in this study was preferred as macro modeling since the units forming the masonry structure are considered as a single homogenized material [4].

In addition, the total weight of the structure is $60560 \mathrm{kN}$. The outer wall, inner wall and roof thicknesses of the building were taken as $200 \mathrm{~cm}, 65 \mathrm{~cm}$ and $40 \mathrm{~cm}$ respectively [4].

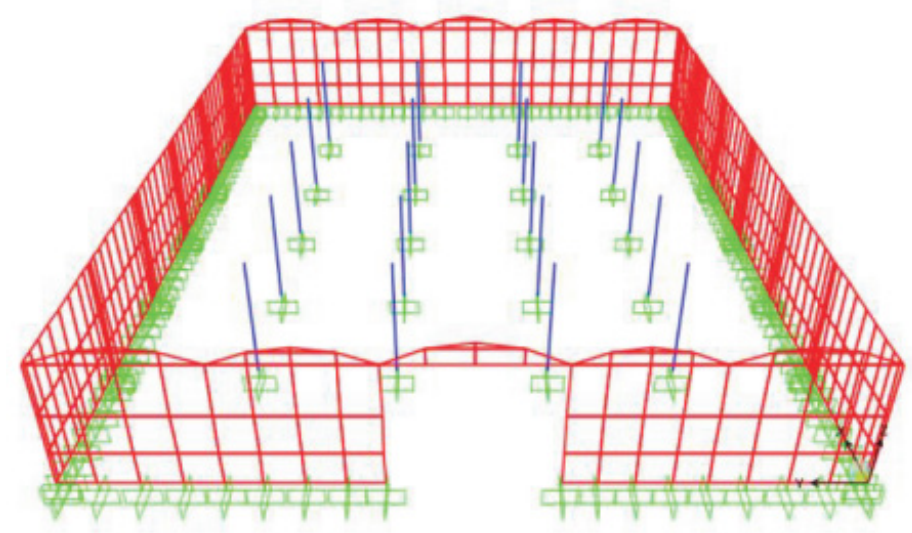

Figure 10: View of Columns and External Walls of The Khan
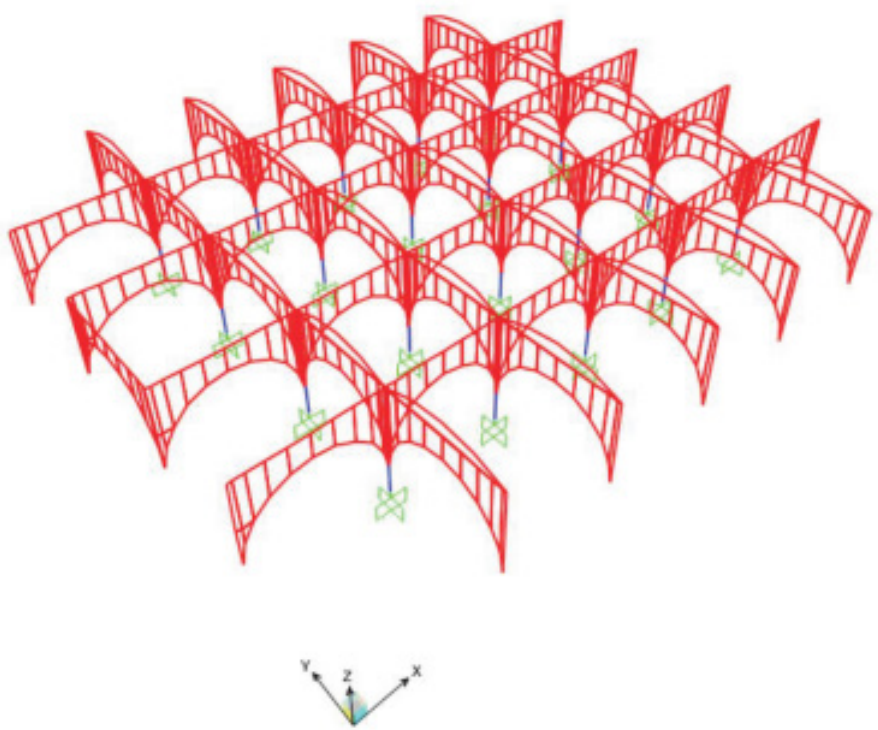

Figure 11: The Model without External Walls and Roof 


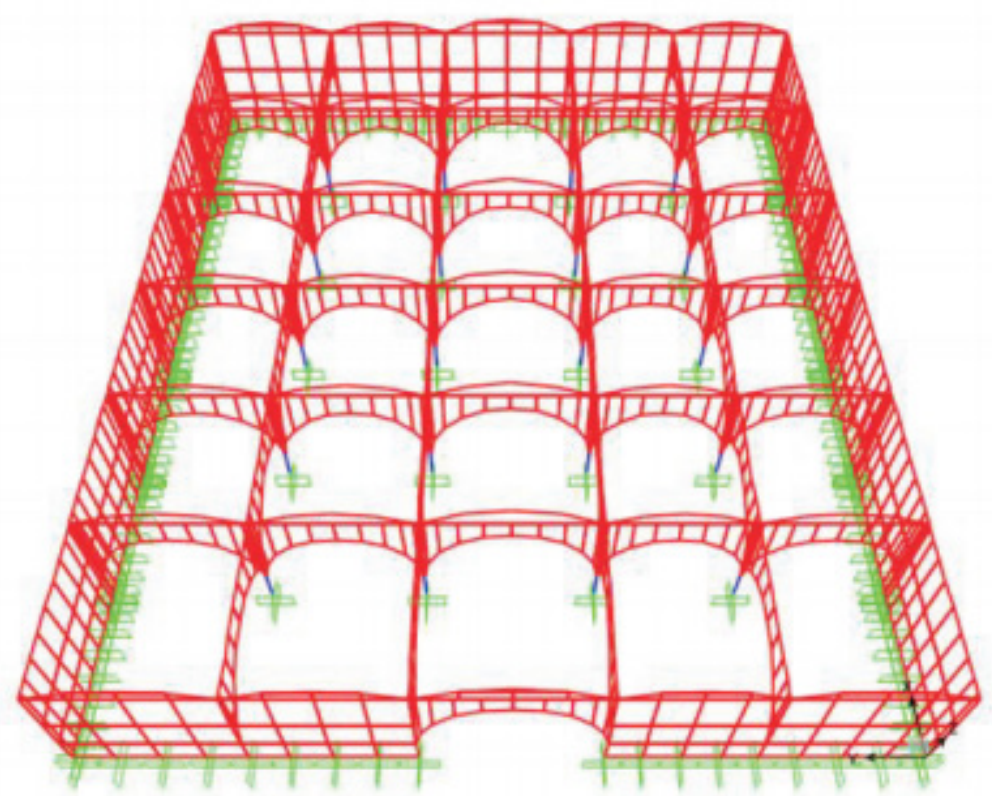

Figure 12: The Model without Roof

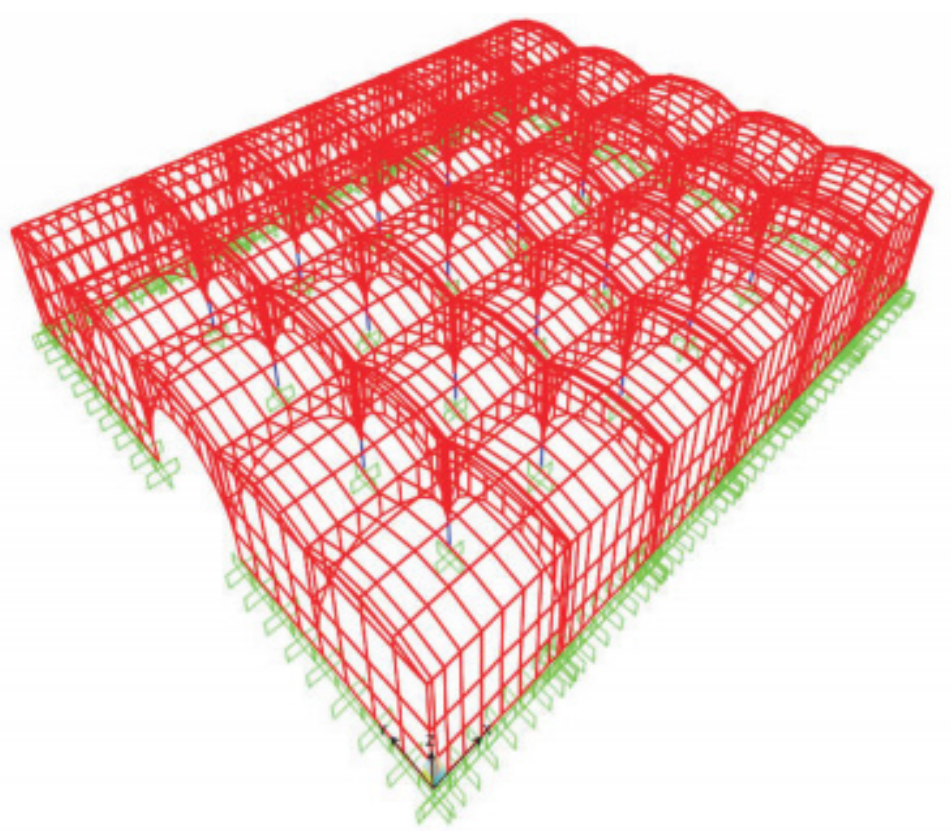

Figure 13: Shell and Frame Model 


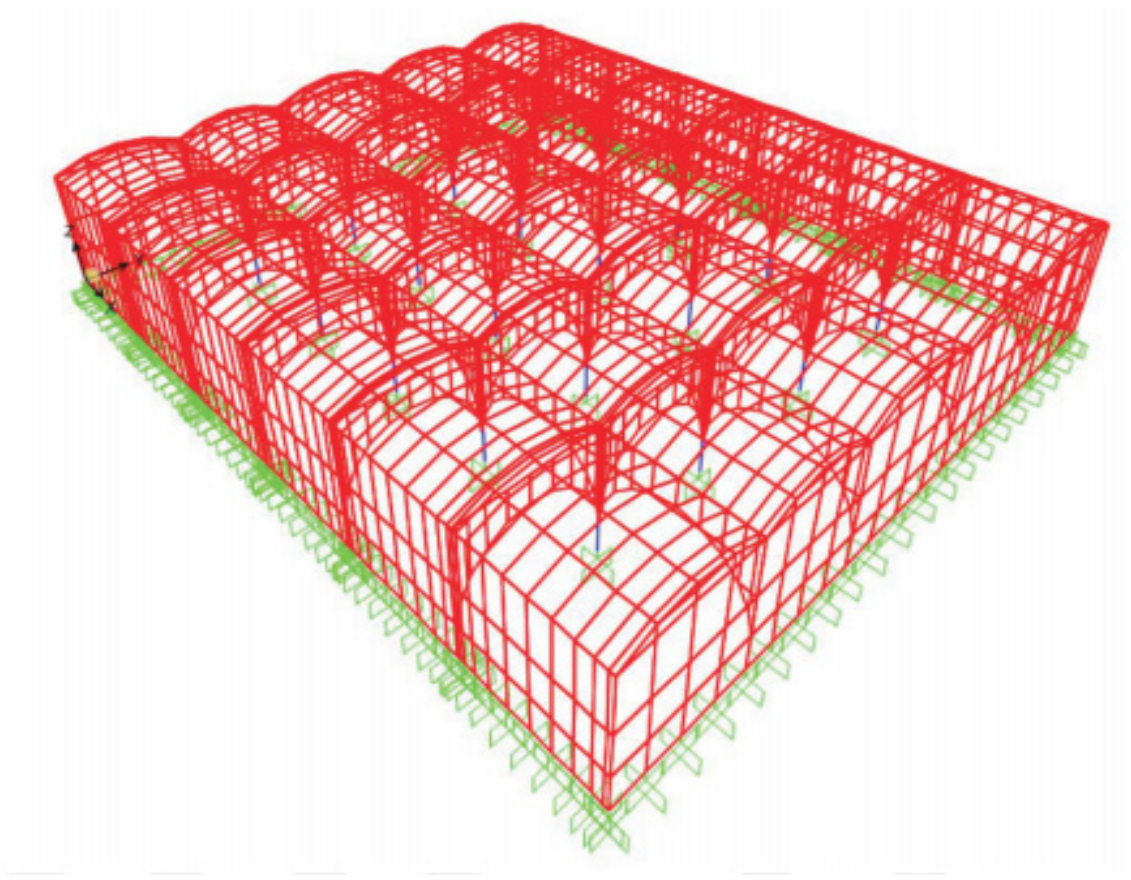

Figure 14: Back View of Shell and Frame Model

\section{CONCLUSION AND RECOMMENDATION}

Çardak caravanserai is a document reflecting the structural characteristics of the Seljuk period. It repeats the majority of the widespread characteristics, but there are a few peculiarities such as the two rectangular platforms, variation in the form of the buttresses, and masonry stairs providing access to the terrace roof.

In order to check for the validity of the finite element model operational modal analysis might be run and a calibration to the FEM model can be processed. The soil conditions need to be investigated as well to better assess the current situation. Material characterization and property estimation should be carried out in order to better represent them in the FEM model. In-situ and laboratory testing would be quite instrumental. Consolidation would be the first choice for preventive conservation. This would aim to restate the capacity with techniques such as injection of repair grout, and restating any loose units and completion of minor material losses.

Detailed structural analyzes and results are given in the master thesis "Structural Analyses and Assessment of Historical Çardak Caravanserai” published in 2019. 


\section{REFERENCES}

[1] Kutlu M. (2009), Seljuk Caravanserais in The Vicinity of Denizli; Han-Abad (ÇardakHan) and Akhan, MSc. Thesis, Bilkent University, Ankara.

[2] Uzunçarşı1ı İsmail Hakkı. (1929), Kitabeler 2, İstanbul.

[3] Şahin E. (2019), Structural Analyses and Assessment of Historical Çardak Caravanserai in Denizli, Master Thesis, Izmir Institude of Technology, Izmir.

[4] Şahin E. (2020), Structural Performance Evaluation of Historical Çardak Caravanserai in Denizli by Performing Linear Analyses, 9th INTERNATIONAL CONFERENCE ON ENGINEERING AND NATURAL SCIENCES, ISBN: 978-625-7720-06-9, (Tam Metin/ Sözlü Bildiri), 160-172, Issued: 01.12.2020.

[5] Bayram A., Nalça C., Keke B., Özel E., Özdemir E., Yönetken E., Eken E., Durmuşlar F., Şener İ., Ergin M., Birgin Ö., Yönder M. (2017), Restoration Project of Çardak Khan Denizli, Design in Architectural Restoration II, 2016-2017 Spring Semester, Supervisors: M. Hamamcioğlu Turan and K. Çelik, Izmir Institute of Technology (IZTECH), Department of Architectural Restoration, Izmir.

[6] Vakıflar Genel Müdürlüğü, 2016, “Tarihi Yapılar İçin Deprem Risklerinin Yönetimi Kilavuzu” https://www.vgm.gov.tr/organizasyonlar/Documents/Sablon+pdf 25/04/2019.

[7] Dabanlı Ö. (2008), Tarihi Yığma Yapılarının Deprem Performansının Belirlenmesi, Yüksek Lisans Tezi, İstanbul Teknik Üniversitesi, İstanbul.

[8] Kömürcü S. (2017), Analysis and Modelling of The In-Plane Behavior of Masonry Walls, MSc. Thesis, Istanbul Technical University, İstanbul. 